\title{
The Effect of Time Management and Communication on Employee Performance with Mediation of Work Motivation in The Kepeng Money Crafts Industry, Kamasan Village, Klungkung District
}

\author{
Made Ermawan Yoga Antara, Ni Wayan Sitiari and I Wayan Gde Sarmawa* \\ Postgraduate Masters Program in Management, Warmadewa University, Bali, Indonesia \\ *Email:yoga4ntara@gmail.com
}

\begin{tabular}{|l|}
\hline \multicolumn{1}{|c|}{ Published: 30/09/2021 } \\
\hline How to cite (in APA style): \\
Antara, M, E, Y., Sitiari, N, W., Sarmawa, I, W, G. (2021). Tourism Finance: The Effect of Time Management and Com- \\
munication on Employee Performance with Mediation of Work Motivation in The Kepeng Money Crafts Industry, Kama- \\
san Village, Klungkung District. Jurnal Ekonomi dan Bisnis Jagaditha, 8(2), 117-126. doi: https://doi.org/10.22225/ \\
jj.8.2.2021.117-126
\end{tabular}

\begin{abstract}
One of the efforts to improve employee performance is through improvements in time management and communication within the organization. The increasing of time management and communication is expected to increase work motivation for employees. The increasing of employee's motivation is also expected to have an impact on improving the performance of the employees themselves. This study aims to examine the employee performance through time management, communication and work motivation that was conducted at the Kepeng Money Craft Industry in Kamasan Village, Klungkung District, which involving all 40 company employees as research respondents. This research was conducted in a census. The distribution of questionnaire to the respondents is the method used in collecting the data, then the data is processed using the Structural Equation Modeling Partial Least Square (PLS) method, through the SmartPLS 3.0 program, at a significance level of $0.05(5 \%)$. The results of this study found that time management, communication, and work motivation each had a positive and significant effect on employee performance. Time management has a significant positive effect on work motivation. Time management has a significant positive effect on employee performance. Communication has a significant positive effect on work motivation. Communication has a significant positive effect on employee performance. Work motivation has a significant positive effect on employee performance. Work motivation mediates some of the effects of time management on employee performance. Work motivation mediates some of the effects of communication on the performance of employees of the kepeng handicraft industry in Kamasan Village, Klungkung Regency.
\end{abstract}

Keywords: communication; employee perfor mance; time management; work motivation

\section{INTRODUCTION}

Kamasan Village, located in Klungkung Regency, is the village that produces the most number of household craft industries in the Klungkung District, totaling 200 industries. The household handicraft industry is divided into several types of industries such as food and beverage, textiles, metal goods, non-metal minerals, iron and steel, paper, and others. One of Kamasan Village handicraft products is
Balinese Uang Kepeng (Bali: Pis Bolong). Balinese coins (pis bolong) have been a part of Balinese society since long ago. This Uang Kepeng in the past served as a means of payment and materials for yadnya or religious ceremonies. The development of the Uang Kepeng handicraft industry in Kamasan Village, Klungkung Regency currently faces obstacles similar to those experienced by other small and medium industries where the main problem is in terms of labor where employee 
performance is still low and there is little time spent working (Parinduri, 2014) this has an impact on productivity.

Robbins (2006) defines performance is the result of work done by employees in accordance with the objectives to be achieved in the work performed. Employee performance is a form of behavior of people or organizations with achievement orientation (Rusman, 2011:50). According to Mangkunegara (2010:55), performance (work performance) is the result of quality and quantity of work achieved by an employee in carrying out their duties in accordance with their responsibilities. An important component in providing space for the realization of employee's personal creativity to move with confidence, build creativity, in producing meaningful performance is time management (Zampetakis, Bouranta, \& Moustakis, 2010).

One of the factors that influence employee performance in an organization is time management. The relationship between time management and performance shown by Ugwulashi (2013) in time management research is considered as one of the factors that can lead to increased performance more efficiently and effectively. Technological progress in the current era of globalization coupled with high global business competition, time management is considered as one of the most effective management principles to reach the peak of an organization's success.

Adu-oppong et al. (2014) explained that every activity allocated would be achieved in the organization if it effectively used the time. Time is used to maintain and control the course of all tasks on effective and quality inspection and supervision in the workplace. Effective time ensures unambiguous goals, proactive planning, priorities and well-defined actions and participates in the delegation of successful activities. Time management acts to take the initiative in order to produce work that provides benefits for organizational goals.

Time management is defined as planning, organizing, mobilizing and controlling the productivity of time. Time is one of the resources that must be managed properly so that individuals or organizations can achieve their goals effectively and efficiently. Time management is a broad concept of various variations associated with improved performance Macan (1994). Time management is the best method for using time, namely: setting priority goals, making plans, and recording the results of inspections of work to achieve personal goals in work and create a direct relationship with daily activities and ensure the progress of a job (Deschamps \& Mattijs, 2017). Time management has a positive effect in improving employee performance for achieving organizational goals (Ziekye, 2016). Time management techniques promote performance and give more time to carry out higher priority tasks (Thomack, 2012).

Another factor that also has an influence on employee performance other than time management is communication. Communication is the key to opening a cooperative relationship between employees and employees and leaders. Through communication a person can convey the desires that are hidden in his heart to others, either through sound, gestures or limbs and so on. The more smooth and fast the communication is carried out, the faster the work relationship can be established. According to Fahmi (2016:163) communication is the process of delivering messages or intentions carried out through one party or person to another party or person whether done directly or through the media.

Interviews with the number of respondents were limited to the Uang Kepeng handicraft industry in Kamasan Village, conducted to find out more in detail about the phenomena that occurred in the field. The interview found a number of facts related to employee performance that is still low and not optimal, especially from the point of view of time management and communication. This condition is caused by various kinds of obstacles or problems in managing time including: 1) employees often procrastinate; 2) employees are often absent and work less than office hours; 3 ) employees are more concerned with personal matters outside the office; 4) employees often arrive late at the office; 5) employees often neglect their duties during work hours. In addition to problems in managing time, there are also communication constraints in the environment of the Uang Kepeng handicraft industry in Kamasan Village, such as: 1) work instructions are often not conveyed clearly; 2) employees are indifferent and rarely greet; 3) employees are rarely involved in discussions around tasks and; 4) employees are too focused on gadgets rather than interacting between employees. This results in not achieving the target work output in terms of both quantity and quality so that it then has an impact on the performance of the employees of the Kepeng handicraft industry in Kamasan Village. 
Research by Khan et al. (2016) found that there was a significant relationship between teacher time management and their performance at the secondary level. That is, teachers who have better time management techniques, show high performance. On the other hand, teachers with poor time management show poor performance in class. Another study, Qteat \& Sayej (2014) also found a significant influence between time management and nursing performance. However, research by Abbasnejad et al., (2013) produced different findings, where time management did not significantly influence the performance of physical education teachers and other teachers.

The results of research from Raza et al. (2017) regarding the relationship between HR practices, communication at work, and employee performance prove that communication at work has a very important and positive impact on employee performance. Nebo et al. (2015) in their research on the role of effective communication on performance also found that there was a significant relationship between effective communication and employee performance. Anto et al's research (2015) also found that Interpersonal Communication has a significant effect on employee performance. However, different results were obtained from Maria's research, (2019) where the results showed that there was no significant effect between communication on employee performance, which means employees who have high interpersonal communication might not necessarily have high performance. Other studies from Valaei \& Jiroudi (2016) also produce insignificant findings on the relationship between communication and employee performance.

The results of research on the effect of time management and communication on employee performance did not show consistent results where several studies found that time management and communication had a significant effect on employee performance, while several other studies found the opposite results of time management and communication not having a significant effect on performance the employee. The difference between the results of these studies makes the research gap raised in this study by adding one mediating variable, namely work motivation.

Robbins (2006) defines motivation as a willingness to make high efforts towards organizational goals which are conditioned by the ability of those efforts to meet individual needs. Motivation is the desire found in someone who stimulates to take an action. Motivation is a process in which various needs encourage a person to carry out a series of activities that lead to the achievement of a certain goal (Mangkunegara, 2010).

Some researchers have conducted studies on the relationship of motivation to employee performance. Ganta (2014) states motivation is very important for every company in an effort to improve employee performance and organizational productivity. Manzoor, (2011), Beltrán-Martín \& Bou-Llusar (2018), Rita et al. (2018), and Rukmana et al. (2018) find evidence that work motivation has a significant effect on employee performance. The results of these studies show empirical evidence that motivation is an important factor in improving employee performance.

Based on the phenomena and the results of studies of the previous studies described above, differences are still found, so this study aims to fill these gaps with an integrated model approach to examine employee performance through time management, communication, and work motivation variables at the Kepeng Money Craft Industry in Kamasan Village, Klungkung District.

\section{CONCEPT AND HYPOTHESIS}

\section{Time Management}

Golabli et al. (2013) defines optimal time management as follows: 1) controlling and managing the pressure and flow of daily tasks; 2) reduce individual anxiety and stress; 3 ) better time management techniques and technologies are expected to have an effective role in improving operations. Adu-oppong et al. (2014) states that time management is a type of skill related to all forms of efforts and actions of a person that are carried out in a planned manner so that individuals can make the best use of their time. Time management according to Akcoltekin (2015), is a personal process by utilizing analysis and planning in using time to increase effectiveness and efficiency. Channar et al. (2014) said that time management is a way of making time under control so as to ensure the creation of effectiveness and efficiency of productivity. Kouali \& Pashiardis (2015) defines it as the power of individuals to set certain targets among various priorities which are mostly very important, and achieve the specified targets, the skill of using certain time periods that is most efficient to achieve a goal.

Time management measurement indicators in this study refer to some of the 
most appropriate indicators based on the definitions and theories of time management. This is based on the suitability between the factors to measure time management in the dimensions of assessment which includes (Ahmad et al. 2012; Azar \& Zafer, 2013; Aduoppong et al. 2014; Akcoltekin, 2015): 1) setting priority goals, focusing on priority standards setting goals and work activities as well as utilizing time as efficiently as possible in carrying out tasks and work, 2) making plans and arranging schedules, which refers to the planning of a work to be carried out in accordance with the target time, 3) recording and checking, namely recording the work that has been scheduled to be re-examined to find out whether the work has been done or not. Based on the results of the study, the research hypothesis was built, namely:

Hypothesis 1: Time management has a positive and significant effect on work motivation

Hypothesis 2: Time management has a positive and significant effect on employee performance

\section{Communication}

Communication is a process of delivering information from one person to another in the hope that there will be a common understanding and perception which will then be directed to a certain action to achieve the goals that have been set in advance (Gorda, 1994:193). Communication is very important in the organization, because communication acts as a coordination chain between employees and organizational functions (Manullang, 2001:209). According to Supadi, (2002:81), communication is an effort to encourage others to interpret opinions as what is desired by those who have these opinions, so that it is expected to obtain a point of mutual understanding. Based on the description above, it can be concluded that communication is a process of delivering information from one person to another, giving rise to an interaction between the two parties to be able to understand each other and achieve a goal. Effective communication according to Tubbs \& Moss (1974) includes: understanding, pleasure, influencing attitude, good social relations, and action. Based on the results of the study, the research hypothesis was built, namely:

Hypothesis 3: Communication has a positive and significant effect on work motivation

Hypothesis 4: Communication has a positive and significant effect on employee performance

\section{Work Motivation}

According to Ardana et al. (2012:193), motivation is the force that drives someone to do something that is essentially internal or external that can be positive or negative, and to direct it highly depends on the toughness of the manager. While work motivation is something that can cause encouragement or enthusiasm for work. According to Rivai (in Kadarisman (2012:276), motivation is a series of attitudes and values that influence individuals to achieve specific things in accordance with individual goals. A slightly different thing was expressed by Stokes (in Kadarisman (2012:278), work motivation is someone's motivation to do a better job. Greenberg (in Wibowo, 2013:379) states motivation is a series of processes that have the ability to arouse (direct), direct (direct), and maintain (maintain) human behavior toward achieving goals. Wibowo (2013) concluded that motivation is an impetus for a series of processes of human behavior in efforts to achieve goals. Robbins \& Judge, (2013:202) defines motivation as a process that takes into account the intensity, direction, and persistence of individual efforts to achieve goals.

Indicators of measurement of work motivation in this study use the theory of needs from McClelland (Robbins \& Judge, 2013:203) which include: 1) the need for achievement is the drive to excel, to achieve that is related to a set of standards, 2) the need for power is the need for get others to behave in ways they don't want, 3) the need for affiliation is the desire for friendly and close interpersonal relationships. Based on the results of the study, the research hypothesis was built, namely:

Hypothesis 5: Work motivation has a positive and significant effect on employee performance

Hypothesis 6: Work motivation acts as a mediator of the effect of time management on employee performance

Hypothesis 7: Work motivation acts as a mediating effect between communication on employee performance

\section{Employee Performance}

Performance is the result obtained by an organization both profit oriented and non profit oriented organizations produced over a certain period of time (Fahmi, 2016:127). Meanwhile, 
according to Torang (2013:74), performance (perfomance) is the quantity and or quality of the work of individuals or groups in the organization in carrying out basic tasks and functions based on standard operational procedures, criteria, and measurements that have been set or applicable in the organization.

According to Moeheriono, (2012:95), performance or performance is a description of the level of achievement of the implementation of a program of activities or policies in realizing the goals, objectives, vision and mission of the organization set in strategic planning. Rivai \& Sagala (2011:548) define performance as real behavior displayed by everyone as work performance produced by employees in accordance with their respective roles in the company. Performance is basically what is done or what is not done by employees (Mathis \& Jackson, 2006:378). Employee performance indicators in this study use criteria in performance measurement which was also stated by Wirawan (2013:69) consisting of: 1) quantity of work, 2) quality, 3 ) timeliness of implementation or completion of work, 4) effectiveness of using resources organization, 5) methods of carrying out work.

\section{METHOD}

The population in this study were all employees in Kamasan village Kepeng money industry with a total of 40 employees. The sample in this study amounted to 40 respondents. The sampling technique used is saturated sampling. The instrument used in this study was a questionnaire. The determination of the score uses a five-level Likert scale (Likert scale). Data collection in this study was carried out by distributing questionnaires that had been compiled in research on the variables to be examined. The data collection process was carried out for two months from November to December 2019. The questionnaires distributed amounted to 40 questionnaires to employees of the Kamasan village Kepeng handicraft industry. Descriptive analysis used in this study was to describe the characteristics of research respondents viewed from several research variables concerning respondents' perceptions of time management, communication, work motivation, and employee performance. The assessment is based on the average score of respondents' perceptions with the following criteria:

$$
\begin{aligned}
& 1.00-1.80 \text { Not very good / Very low } \\
& 1.81-2.60 \text { Not good / Low }
\end{aligned}
$$

\subsection{1 - 3.40 Good enough}

$3.41-4.20$ Good / High

\subsection{1 - 5.00 Very good / Very high}

Quantitative analysis is used to analyze the relationship between variables in this study, namely time management, communication, work motivation, and employee performance. In analyzing the influence between exogenous variables and endogenous variables in this study the Partial Least Square (PLS) statistical method was used. Because this method is known to be very practical and does not require many assumptions including the assumption of a normal distribution. According to Jogiyanto (2009), PLS is a variance-based analysis of structural equations (Structural Equation Modeling) that can simultaneously test structural models. The measurement model is used to test the validity and reliability, while the structural model is used to test causality (hypothesis testing with predictive models).

\section{RESULT AND DISCUSSION}

\section{Results of Inferential Analysis}

\section{Measurement Model Testing Results (Outer- Model)}

Convergent validity is a criterion for determining the validity of indicators on each latent variable. Validity evaluation is done by looking at the outer loading value of each indicator against its latent variable. An indicator is valid if the outer loading coefficient is greater than 0.50 and significant ( $t$-statistics $>1.96)$ and has the same coefficient (covari). The outer loading coefficient indicates the magnitude of the contribution of the indicator to its latent variable. This gives meaning, that the greater the outer loading coefficient indicates the greater contribution of the indicator to the latent variable. Based on the results of data processing shows all indicators have an outer loading value $>0.50$ so that all indicators can be said to be valid. Furthermore, seen from the composite reliability value and Cronbach's Alpha> 0.70, then based on that all indicators are said to be reliable.

Discriminant validity is a validity criterion performed by looking at: 1) The square roof coefficient of variance extracted ( $\sqrt{\mathrm{AVE}})$ is greater than the correlation between constructs, 2) the recommended AVE value is greater than 0.5 (Lathan and Ghozali, 2012:79 ). From the two requirements for good discriminant validity, the value of AVE $>0.5$ 
has been fulfilled, but the condition $\sqrt{ }$ AVE $>$ correlation between constructs, there is a value of correlation between constructs of 0.837 that exceeds $\sqrt{ }$ AVE.

The outer model evaluation results which are based on the criteria of convergent validity, discriminant validity, composite reliability, and Cronbach's Alpha, indicate that they meet the validity and reliability testing criteria, then each indicator can be declared valid and reliable.

\section{Test Results of Measurement Model (Inner- Model)}

Criteria for testing the measurement models in this study are shown based on a number of criteria, namely: R-Square $\left(\mathrm{R}^{2}\right)$, QSquare Predictive $\left(\mathrm{Q}^{2}\right)$, Goodness of Fit $(\mathrm{GoF})$.

$\mathrm{R}$-Square value $\left(\mathrm{R}^{2}\right)$ for work motivation variable (Y1) is 0.563 and employee performance (Y2) is $0.809 . \mathrm{R}^{2}$ value of 0.563 for work motivation variables means that the variation of work motivation $56.3 \%$ is influenced by variations in time management and communication, the rest $(43.7 \%)$ is influenced by variations in other factors outside the research model. $\mathrm{R}^{2}$ value of 0.809 on employee performance variables means that $80.9 \%$ variation in employee performance is influenced by variations in time management, communication, and work motivation, the rest $(19.1 \%)$ is a variation of other factors. Referring to the criteria set by (Hair et al; Latan \& Ghozali, 2012:85), that the $\mathrm{R}^{2}$ value is relatively high.

$Q^{2}$ Predictive Relevance is a measure of how good observations can be generated by the research model where the value is calculated by the formula:

$$
\mathrm{Q}^{2}=1-\left\{\left(1-\mathrm{R}^{2} \mathrm{Y}_{1}\right)\left(1-\mathrm{R}^{2} \mathrm{Y}_{2}\right)\right\}
$$

$$
\begin{aligned}
& \mathrm{Q}^{2}=1-\{(1-0,563)(1-0,809)\} \\
& \mathrm{Q}^{2}=1-\{(0,437)(0,191)\} \\
& \mathrm{Q}^{2}=1-0,0835 \\
& \mathrm{Q}^{2}=0,9165 \\
& \mathrm{Q}^{2} \text { calculation results show a value of }=
\end{aligned}
$$
0.9165 which means that $91.65 \%$ of the relationship between latent variables can be explained strongly by the research model, while the remaining $8.35 \%$ is another factor not taken into account in the research model.

Goodness of Fit (GoF) is a criterion to determine the level of accuracy (fit) of the model. The GoF calculation formula is as follows (Hussain et al., 2018):

$$
\begin{aligned}
& \mathrm{GoF}=\sqrt{ }\left(\overline{\mathrm{A}} \overline{\mathrm{V}} \overline{\mathrm{E}} \times \overline{\mathrm{R}}^{2}\right) \\
& \mathrm{GoF}=\sqrt{ }[\{(0,515+0,571+0,522+0,558) / 4\} \mathrm{x} \\
& \{(0,563+0,809) / 2)\}] \\
& \mathrm{GoF}=\sqrt{ } 0,542 \times 0,686 \\
& \mathrm{GoF}=0,6098
\end{aligned}
$$

GoF calculation results show a value of 0.6098 , based on GoF criteria according to Latan and Ghozali (2013:86), the above values are classified as high GoF. This means that the research model has a high degree of accuracy.

\section{Hypothesis Testing Results}

\section{Testing the Direct Effect}

The direct influence test consists of five hypotheses, namely: 1) the effect of time management on work motivation, 2) the effect of time management on employee performance, 3) the effect of communication on work motivation, 4) the effect of communication on employee performance, and 5 ) the effect of work motivation on employee performance. The results are shown in Figure 1 and Table 1.

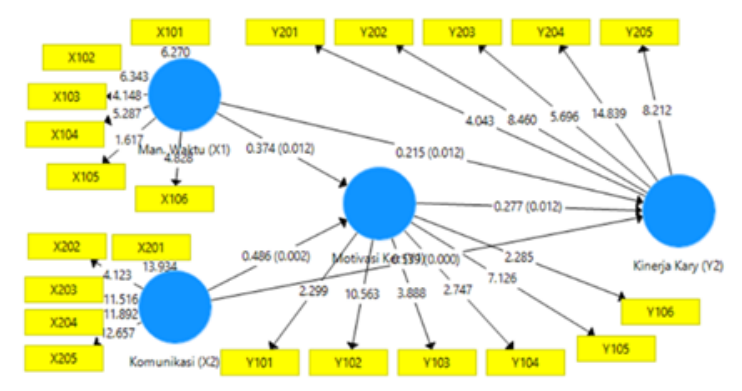

Figure 1. Path Coefficient of Time Management, Communication, Work Motivation, and Employee Performance Variables 
Table 1. Direct Influence of Time Management, Communication Variables, Work Motivation, and Employee Performance

\begin{tabular}{cccccc}
\hline $\begin{array}{c}\text { Relationship Between } \\
\text { Variables }\end{array}$ & $\begin{array}{c}\text { Coefficient of Direct } \\
\text { Effect }\end{array}$ & t-statistics & t-tabel & p-value & $\begin{array}{c}\text { Remar } \\
\text { k }\end{array}$ \\
\hline $\mathrm{X} 1 \rightarrow \mathrm{Y} 1$ & 0,374 & 2,518 & $>1,96$ & 0,012 & Sig \\
$\mathrm{X} 1 \rightarrow \mathrm{Y} 2$ & 0,215 & 2,517 & $>1,96$ & 0,012 & Sig \\
$\mathrm{X} 2 \rightarrow \mathrm{Y} 1$ & 0,486 & 3,099 & $>1,96$ & 0,002 & Sig \\
$\mathrm{X} 2 \rightarrow \mathrm{Y} 2$ & 0,539 & 6,521 & $>1,96$ & 0,000 & Sig \\
$\mathrm{Y} 1 \rightarrow \mathrm{Y} 2$ & 0,277 & 2,512 & $>1,96$ & 0,012 & Sig \\
\hline
\end{tabular}

Source: data processed, 2019

Based on the results of data processing shown through Figure 1 and Table 1 can be explained as follows:

1) The Effect of Time Management on Work Motivation

Time management shows a positive and significant effect on work motivation where the path coefficient shown is 0.374 with $\mathrm{t}$ statistics of $2.518>1.96$. The results of this test indicate that Hypothesis $1(\mathrm{H} 1)$ which states that time management has a positive and significant effect on work motivation can be accepted. This indicates that the higher the time management, the work motivation will also increase.

2) The Effect of Time Management on Employee Performance

Time management shows a positive and significant effect on employee performance where the path coefficient shown is 0.215 with t-statistics of 2.517> 1.96. The results of this test indicate that Hypothesis 2 (H2) which states that time management has a positive and significant effect on employee performance can be accepted. This indicates that the higher the time management, the employee's performance also increases.

3) The Effect of Communication on Work Motivation

Communication shows a significant effect on work motivation where the path coefficient shown is 0.486 with t-statistics of 3.099> 1.96 . The results of this test prove that Hypothesis 3 (H3) which states that communication has a positive and significant effect on work motivation can be accepted. This indicates that the better the communication, the work motivation will also increase.

4) The Effect of Communication on Employee Performance

Communication shows a positive and significant effect on employee performance, where the path coefficient shown is 0.539 with t-statistics of $6.521>1.96$. This test proves that Hypothesis 4 (H4) which states that communication has a positive and significant effect on employee performance can be accepted. This indicates that the better the communication, the employee's performance also increases.

5) The Effect of Work Motivation on Employee Performance

Work motivation shows a significant effect on employee performance where the path coefficient shown is 0.277 with t-statistics of 2.512> 1.96. The results of this test prove that Hypothesis 5 (H5) which states that work motivation has a positive and significant effect on employee performance can be accepted. This indicates that the higher the work motivation, the employee's performance also increases.

\section{Testing for Indirect Effects}

Testing the indirect effect between time management variables on employee performance through work motivation and communication variables on employee performance through work motivation can be seen in Table 2.

Table 2. Indirect Effects of Time Management and Communication Variables Through Work Motivation on Employee Performance

\begin{tabular}{llllll}
\hline Relationship Between Variables & Koef. Indirect Influence & t-statistics & t-tabel & p-value & Remark \\
\hline $\mathrm{X} 1 \rightarrow \mathrm{Y} 1 \rightarrow \mathrm{Y} 2$ & 0,120 & 1,966 & $>1,96$ & 0,048 & $\mathrm{Sig}$ \\
$\mathrm{X} 2 \rightarrow \mathrm{Y} 1 \rightarrow \mathrm{Y} 2$ & 0,134 & 2,022 & $>1,96$ & 0,044 & $\mathrm{Sig}$ \\
\hline
\end{tabular}

Source: data processed, 2019 
1) The Role of Work Motivation in Mediating the Effect of Time Management on Employee Performance

Work motivation is able to mediate the relationship between time management and employee performance, where the value of indirect path coefficient is 0.120 with $t$ statistics $1.966>1.96$. The results of this test prove that Hypothesis 6 (H6) which states that work motivation acts as a mediator of the influence between time management on employee performance is acceptable. This indicates that work motivation plays a partial mediation (partial mediation) effect of time management on employee performance.

2) The Role of Work Motivation in Mediating the Effects of Communication on Employee Performance

Work motivation is able to mediate the communication relationship to employee performance, where the value of indirect path coefficient is 0.134 with t-statistics $2.022>$ 1.96. The results of this test prove that Hypothesis 7 (H7) which states that work motivation acts as a mediating effect between communication on employee performance can be accepted. This indicates that work motivation plays a partial mediation (partial mediation) effect of communication on employee performance.

\section{CONCLUSION}

Based on the result and discussion described above, it can be concluded that time management has a positive and significant effect on work motivation. The results of this study indicate that the better the time management, the higher the work motivation of Kepeng handicraft industry employees in Kamasan Village. Time management has a positive and significant effect on employee performance. The results of this study mean that the better the time management, the higher the performance of the Kepeng handicraft industry employees in Kamasan Village. Communication has a positive and significant influence on work motivation. This gives the meaning that the better the communication the higher the work motivation of Kepeng money craft industry employees in Kamasan Village. Communication has a positive and significant effect on employee performance. This gives an indication that the better the communication, the higher the performance of Kepeng money craft industry employees in Kamasan Village. Work motivation has a positive and significant effect on employee performance. This gives an indication that the higher the work motivation, the higher the performance of Uang Kepeng craft industry employees in Kamasan Village. Work motivation has the role of partially mediating the influence of time management on employee performance. This gives an indication that good time management, coupled with high work motivation, can improve the performance of employees of the Kepeng Crafts industry in Kamasan Village. Work motivation has the role of partially mediating the effect of communication on employee performance. This gives an indication that good communication, coupled with high work motivation, can improve the performance of the Uang Kepeng handicraft industry employees in Kamasan Village. Therefore, there are some suggestions to be given to management of the Kameng Desa Kepeng handicraft industries are: 1) Trying to improve indicators of time management that are still lacking compared to other indicators, namely making a list of activities, and marking each activity. 2) Trying to improve indicators of communication that are still lacking compared to other indicators, namely carrying out tasks with pleasure and social relations such as celebrating company birthdays. 3) Trying to increase the indicator of work motivation which is still less than other indicators, namely influencing others and becoming part of the group. 4) Try to improve indicators of employee performance that are still lacking compared to other indicators, namely speed in working, prioritizing basic tasks, and being able to work together. 6) To overcome the decline in employee performance, companies are advised to pay more attention to employee work motivation, especially giving awards to employees who excel. 6) It is recommended to management to pay more attention to employees, such as the presence of employees to come and go home from work on time, and employees do not leave work during working hours. It is also recommended for further research to include other variables that have the potential to influence employee performance in addition to time management and communication variables, such as organizational culture, work environment, leadership, discipline, employee competence, and other relevant variables.

\section{REFERENCES}

Abbasnejad, E., Farahani, A., \& Nakhaei, A. (2013). The relationship between time management and job stress in teachers of physical education and non physical education. Advances in Environmental 
Biology, 7(8), 1340-1347.

Adu-oppong, A. A., Agyin-birikorang, E., Darko, G. M., \& Aikins, E. D. (2014). Time Management and Administrative Effectiveness: Lessons for Educational Administrators. Global Journal of Interdisciplinary Social Sciences, 3(4), 7682.

Ahmad, N. L., Mohd. Yusuf, A. N., Mohamed Shobri, N. D., \& Wahab, S. (2012). The Relationship between Time Management and Job Performance in Event Management. Procedia - Social and Behavioral Sciences, 65(ICIBSoS), 937-941. https:// doi.org/10.1016/j.sbspro.2012.11.223

Akcoltekin, A. (2015). High school students time management skills in relation to research anxiety. Educational Research and Reviews, 10(16), 2241-2249. https://doi.org/10.5897/ err2015.2345

Anto, K. A., Setiawati, D. T., \& Si, M. (2015). The Mediating Role of Organizational Commitment in Influence Relationships Between Interpersonal Communication and Emotional Intelligence Toward Employee Performance. International Journal of Business, Economics and Law, 7(2), 47-56.

Ardana, I. K., Mujiati, N. W., \& Utama, I. W. M. (2012). Manajemen Sumber Daya Manusia. Yogyakarta: Graha Ilmu.

Azar, S., \& Zafer, D. S. (2013). Confirmatory Factor Analysis of Time Management Behavior Scale: Evidence from Pakistan. Interdisciplinary Journal of Contemporary Research In Business, 4(12), 946-959. https://doi.org/10.2466/PR0.80.1.225-226

Beltrán-Martín, I., \& Bou-Llusar, J. C. (2018). Examining the intermediate role of employee abilities, motivation and opportunities to participate in the relationship between $\mathrm{HR}$ bundles and employee performance. BRQ Business Research Quarterly, 21(2), 99-110. https:// doi.org/10.1016/j.brq.2018.02.001

Channar, D. Z. A., Shaikh, S., Pathan, D. P. A., \& Mughal, D. S. (2014). Impact of Time Management on Organizational Performance. The Women-Annual Research Journal of Gender Studies, 6, 47-58. https:// doi.org/10.21522/TIJMG.2015.02.01.Art003

Deschamps, C., \& Mattijs, J. (2017). Sustainable goal setting: a large-scale case in management practice. International Journal of Productivity and Performance Management, 66(8), 1087-1104. https:// doi.org/10.1108/IJPPM-05-2016-0100

Fahmi, I. (2016). Perilaku Organisasi Teori, Aplikasi, dan Kasus. Bandung: Alfabeta.

Ganta, V. C. (2014). Motivation in the Workplace To Improve the Employee Performance. International Journal of Engineering Technology, Management and Applied Sciences, 2(6), 2349-4476.
Golabli, M., Rezaei, S., Najjar, L., \& Nameghi, M. G. (2013). The Survey of Relationship between Time Management with Job Stress and Performance in Material and Procurement Management of N.I.S.O.C ( National Iranian South Oil Company ). Journal of Basic and Applied Scientific Research, 3(10), 33-39.

Gorda. (1994). Manajemen Sumber Daya Manusia. Denpasar: Widya Gematama.

Jogiyanto, A. W. (2009). Konsep dan Aplikasi PLS (Partial Least Square) untuk Penelitian Empiris. Yogyakarta: BPFE.

Kadarisman, M. (2012). Manajemen Pengembangan Sumber Daya Manusia. Jakarta: PT Raja Grafindo Persada.

Khan, H. M. A., Farooqi, M. T. K., Khalil, A., \& Faisal, I. (2016). Exploring Relationship of Time Management with Teachers' Performance. Bulletin of Education and Research, 38(2), 249-263.

Kouali, G., \& Pashiardis, P. (2015). Time management profiles of Cypriot school principals: a mixed-methods approach. International Journal of Educational Management, 29(4), 492-518. https:// doi.org/10.1108/IJEM-02-2014-0019

Macan, T. H. (1994). Time management: Test of a process model. Journal of Applied Psychology, 79(3), 381-391. https:// doi.org/10.1037/0021-9010.79.3.381

Mangkunegara. (2010). Manajemen Sumber Daya Manusia Perusahaan (Cet. ke 6). Bandung: PT. Remaja Rosdakarya.

Manullang, M. (2001). Manajemen Personalia. Yogyakarta: BPEE.

Manzoor, Q.-A. (2011). Impact of Employees Motivation on Organizational Effectiveness. Business Management and Strategy, 3(1), 36 -44. https://doi.org/10.5296/bms.v3i1.904

Maria, E. (2019). The Influence of Organizational Culture, Compensation and Interpersonal Communication in Employee performance Through Work Motivation as Mediation. International Review of Management and Marketing, 9(5), 133-140. https:// doi.org/10.32479/irmm.8615

Mathis, R. L., \& Jackson, J. H. (2006). Human Resource Management: Manajemen Sumber Daya Manusia. Terjemahan Dian Angeli. Jakarta: Salemba Empat.

Moeheriono. (2012). Pengukuran Kinerja Berbasis Kompetensi. Jakarta: Raja Grafindo Persada.

Nebo, C. S., Nwankwo, P. N., \& Okonkwo, R. I. (2015). The Role of Effective Communication on Organizational Performance: A Study Of Nnamdi Azikiwe University, Awka. Review of Public Administration and Management, 4(8). Retrieved from http:// www.arabianjbmr.com/RPAM_index.php 
Parinduri, R. A. (2014). Family Hardship and the Growth of Micro and Small Firms in Indonesia. Bulletin of Indonesian Economic Studies, 50(1), 53-73. https:// doi.org/10.1080/00074918.2014.896237

Qteat, M., \& Sayej, S. (2014). Factors Affecting Time Management and Nurses' Performance in Hebron Hospitals. Journal of Education and Practice, 5(35), 41-59.

Raza, S., Asim, M., Kanwal, R., Sarfraz, U., 5Khushtaba, \& Zahra, M. (2017). The Relationship Between Hrm Practice, Workplace Communication and Job Performance of Service Industries Employees in Vehari, the Relationship Between Hrm Practice, Workplace Communication and Job Performance of Service Industries Employees in Vehari, . International Journal of Information, Business and Management, 9(2), 126-144.

Rita, M., Payangan, O. R., Rante, Y., Tuhumena, R., \& Erari, A. (2018). Moderating effect of organizational citizenship behavior on the effect of organizational commitment, transformational leadership and work motivation on employee performance. International Journal of Law and Management, 60(4), 953-964. https:// doi.org/10.1108/IJLMA-03-2017-0026

Rivai, H. V., \& Sagala, E. J. (2011). Manajemen Sumber Daya Manusia untuk Perusahaan dari Teori ke Praktik (Edisi 2). Jakarta: Rajawali Pers.

Robbins, S. P. (2006). Perilaku Organisasi. Jakarta: PT Indeks Kelompok Gramedia.

Robbins, S. P., \& Judge, T. A. (2013). Organizational Behavior 15th Edition. United States of America: Pearson Education, Inc.

Rukmana, H. D., Sopiah, M. P. M., \& Nora, E. S. E. (2018). The Impact of Organization Communication on Employee Performance Through Employee's Work Motivation at Pt. Putri Panda Unit Ii Tulungagung, East Jawa, Indonesia. KnE Social Sciences, 3(3), 211. https://doi.org/10.18502/kss.v3i3.1885

Rusman. (2011). Keterkaitan antara Semangat Kinerja Guru. Jakarta: Balai Pustaka.

Supardi, S. A. (2002). Dasar-Dasar Perilaku Organisasi. Yogyakarta: UII Press.

Thomack, B. (2012). Time Management for Today's Workplace Demands. Workplace Health \& Safety, 60(5), 201-203. https:// doi.org/10.1177/216507991206000503

Torang, S. (2013). Organisasi dan Manajemen (Perilaku, Struktur, Budaya \& Perubahan Organisasi. Bandung: Alfabeta.

Tubbs, S. L., \& Moss, S. (1974). Human Communication: An Interpersonal Perspective. Michigan: Random House.

Valaei, N., \& Jiroudi, S. (2016). Job satisfaction and job performance in the media industry.
Asia Pacific Journal of Marketing and Logistics, 28(5), 984-1014. https:// doi.org/10.1108/APJML-10-2015-0160

Wibowo. (2013). Manajemen Kinerja. Jakarta: Rajawali Pers.

Wirawan. (2013). Kepemimpinan Teori, Psikologi, Perilaku Organisasi, Aplikasi dan Penelitian. Jakarta: PT Raja Grafindo Persada.

Zampetakis, L. A., Bouranta, N., \& Moustakis, V. S. (2010). On the relationship between individual creativity and time management. Thinking Skills and Creativity, 5(1), 23-32. https://doi.org/10.1016/j.tsc.2009.12.001

Ziekye, J. (2016). Impact of Time Management on Organizational Performance. The WomenAnnual, 2(1), 1-9. 